\title{
Town Hall, Whitehall, and the NHS: health implications of controlling local government
}

\author{
MARK MCCARTHY
}

Now in its second term of office, and with the largest single party parliamentary majority for over 30 years, the Conservative administration led by Mrs Thatcher has turned towards controlling local government. It has set in motion legislation to abolish the Greater London Council and the six metropolitan counties, and has proposed statutory controls over spending by 18 of the remaining 404 local authorities.

Many of our present health services originated in local authorities. The public health acts of the nineteenth century laid duties on local authorities to provide better sanitation and housing. Poor law boards, administered by local authorities from 1929, developed a network of hospitals throughout the country for poor and disabled people, which complemented the charitable hospitals. Almost all hospitals were taken into the National Health Service in 1948, and community health services, developed by the public health departments, were added in 1974. Health care is now provided by an effective quasi-government organisation independent of local authorities. Why should we worry about these new proposals to control local authorities being put before parliament?

\section{Abolition of the Greater London Council and the metropolitan counties}

The structure of local authorities is the result of two sets of reforms following royal commission reports. In 1965 the London conurbation was enlarged from the London County Council boundaries to the new Greater London Council, with 32 London boroughs. In 1974 a further six metropolitan counties were created in the midlands and north of England reflecting similar strategic

Department of Community Medicine, School of Medicine, University College, London WC1E 6JJ

MARK MCCARTHY, MRCP, MFCM, senior lecturer planning needs, and the shire counties and district councils were reformed. A two tier system of local government was created throughout England. One anomaly remained, however. The management of the major spending services (education and personal social services) was with the lower tier in the metropolitan areas and in the higher tier in the shires.

\section{ARGUMENTS}

The Conservative party manifesto at the 1983 general election proposed the abolition of the Greater London Council and the metropolitan counties. The government's plans were placed before parliament in October 1983 in a white paper Streamlining the Cities. ${ }^{1}$ The reasons for abolition were put baldly in 10 short paragraphs and were unsupported by detailed arguments such as a royal commission report. Firstly, because the Greater London Council and metropolitan counties have fewer responsibilities than their equivalent upper tier authorities, the shire counties, the white paper claimed that "the GLC and the metropolitan counties have found it difficult to establish a role for themselves." Secondly, the government pointed to larger than average increases in expenditure by these authorities. The implication was of "rash" spending beyond economic limits. The white paper did not mention, however, that some of the expenditure was balanced by lowering of fares and charges for services, rather than expanding services, and a sizable proportion of the expenditure was incurred by cuts in the government's rate support grant.

The Greater London Council and metropolitan councils have several arguments in favour of their retention. ${ }^{2}$ Firstly, effective strategic planning is still necessary for the development of conurbations if they are not to degenerate into inner city slums and eternal traffic jams. If the Greater London Council is abolished London will be the only capital city in the Western world without a democratically elected strategic local authority. Secondly, some major functions, including the police in the metropolitan counties, fire services, and public transport, are to be transferred to 
autonomous organisations that have no democratic control. The Home Office's record in management of the Metropolitan Police gives no reassurance for external control of London's affairs. Thirdly, there is unlikely to be much reduction in total local government expenditure, since these functions remain necessary and are simply being transferred to other organisations. The complex network of joint committees needed for coordination could well increase bureaucracy. And the experience of the NHS in 1982, when area health authorities were abolished, suggests that redundancy payments will add considerably to the overall costs of change.

The inside story for abolishing the Greater London Council and metropolitan county councils is, of course, recognised by many people. The major conurbations predominantly vote Labour and the shire counties vote Conservative. The government is daily embarrassed by the Greater London Council advertising the number of unemployed people in London by a large notice on the parapet of County Hall, readily visible across the Thames from the Houses of Parliament. Many of the councillors in the Greater London Council and metropolitan counties are of the younger generation, schooled in the late 'sixties, and they are gaining support from unfranchised minorities in urban society, including ethnic minorities, feminists, people with disabilities, and the unemployed. These constituencies urge a greater commitment to public services and reject the government's view that state provision is inherently "bad" whereas competition (and therefore that some people have to be losers) is good.

\section{HEALTH IMPLICATIONS}

We are lucky that these arguments were abandoned for health care in 1948 when the NHS was established. But although the higher tiers of local government have no responsibility for health services, there remain implications in the changes. Several of the departments whose functions would be transferred contribute to the public's health, and a deterioration of these services would be unwelcome if they are devolved to the boroughs. ${ }^{3}$ Perhaps more importantly, the NHS has recently been restructured into two tiers, and a new pattern of cooperation between higher tier local government and the NHS regions could be foreseen. The Greater London Council, for example, established a health panel in 1982 to promote a view which integrates the separate strategies of the four Thames regional health authorities and the special health authorities associated with the postgraduate institutes. What will be most lost by abolition of the Greater London Council, however, is its new found capacity to support local community based initiatives. Although only a small proportion of its total budget, Greater London Council funding for youth schemes, community projects, and health oriented initiatives has been a major release for new, imaginative ideas. ${ }^{4}$ This is the seed corn and without it our future harvest will be meagre.

\section{Rate capping: central control of local government action}

Local authorities receive income from two main sources. They raise rates directly of residential and commercial property within their boundaries, and they receive, on average, a similar amount out of centrally raised taxes as a direct grant from parliament. This grant has become a vital component of local government income, and the rates, because they are a large, single annual payment, have low political appeal. The 1979 Conservative party manifesto promised that the government would reform the rates, but no satisfactory alternative has been found.

The system of differential grant support follows a complex formula that takes population and social characteristics into account and allows central government to redistribute some of the national wealth to meet inequalities locally. Increasingly, this has tied local government to central government's purposes. Parliament does not define exactly how each local authority should spend its income, but the present administration has chosen to recom- mend an upper limit of total expenditure. For 1985-6 any local authority that overspends its target will lose grant support at a rate of $7 p$ in the pound on the rates for the first $1 \%$ over, $8 p$ in the pound for the second $1 \%$, and $9 p$ in the pound for each $1 \%$ thereafter. The Secretary of State for the Environment is also proposing new powers to impose a legal maximum on an authority's spending and rates. This is rate capping.

Eighteen councils in England are spending at least 4\% more than the government's target, and are already having to meet the heavy penalties imposed on their direct grant by raising much higher rates (fig 1). These councils, all but two of which are Labour controlled, will be subject to rate capping, with a cut of $1.5 \%$ off this year's cash budget.

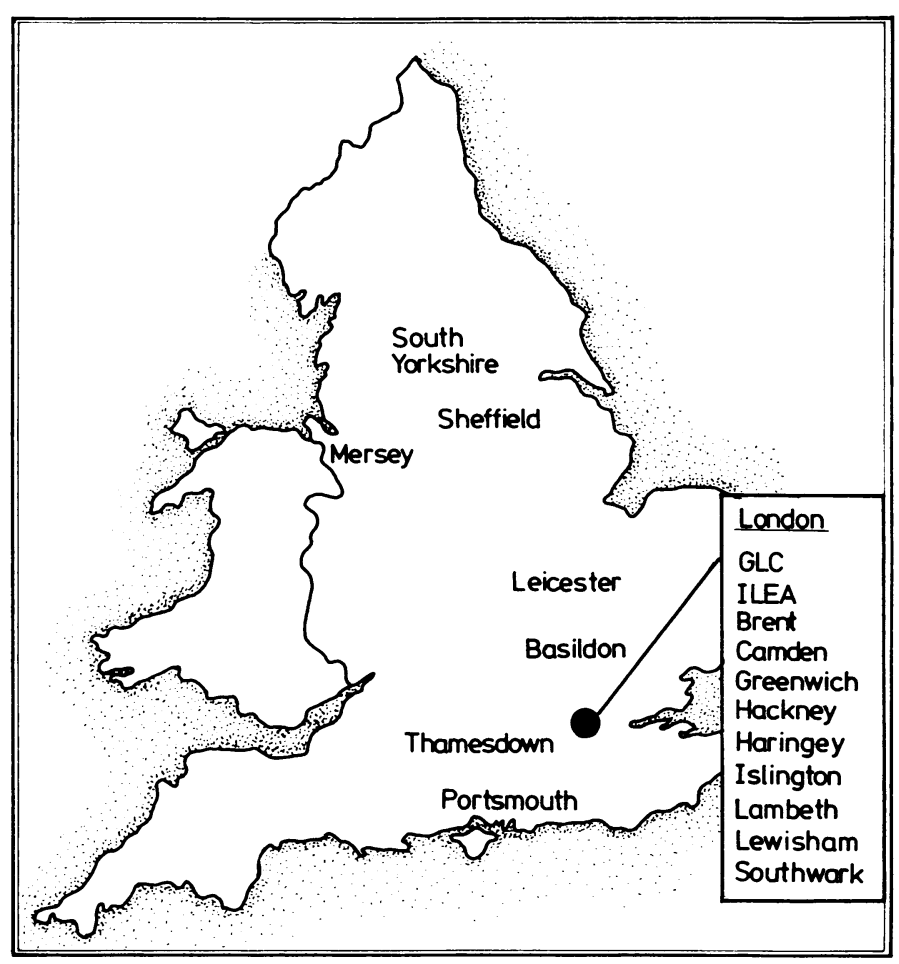

FIG 1-Eighteen authorities proposed for rate capping.

\section{ARGUMENTS}

Rate capping is an expression of the government's desire to reduce the level of public expenditure as a proportion of our total economic activity. At present public expenditure accounts for about $45 \%$ of the gross national product, which the government believes is too high. It has commitments to increase certain areas of public spending-especially the armed forces and the police-and thus seeks to curtail areas of welfare provision to balance this. The argument is not put at the level of social need but of "economic efficiency." Reducing public spending is expected to stimulate private enterprise and production. And public services are asked to increase their "value for money"-a view that we have also had directed at the NHS.

Local authorities show a great range of expenditures, based on a variety of factors, including political history, needs, and their rate base. The three richest authorities are in central London-the City of London, Westminster, and Camden. Labour controlled authorities, with greater social needs, tend to spend more than Conservative controlled authorities. Higher spending councils have argued that penalties in their grant support and rate capping are a violation of the principle of local democracy. It is parliament, after all, that imposes duties on the local authorities to provide public services. That some do this more effectively than others should not, in their eyes, be a cause for complaint. 
The social structure of England is not homogenous. Recent analysis of the 1981 census, for example, has shown that just over half of the population live in urban areas with a population. of 100000 or more. ${ }^{5}$ But there are large gradients in social characteristics between the conurbations and the small towns and rural areas. Figure 2 shows the relation between social class composition and unemployment, and figure 3 shows why the shire counties and outer London boroughs are unenthusiastic about subsidies for public transport.

It is a question of values. The formula to derive the amount of rate support grant that each local authority receives takes account of various sociodemographic factors. But their weighting in the formula is crucial. More weight placed on social deprivation in the formula would yield grants which give more money to inner urban boroughs and less to affluent outer boroughs and the shire

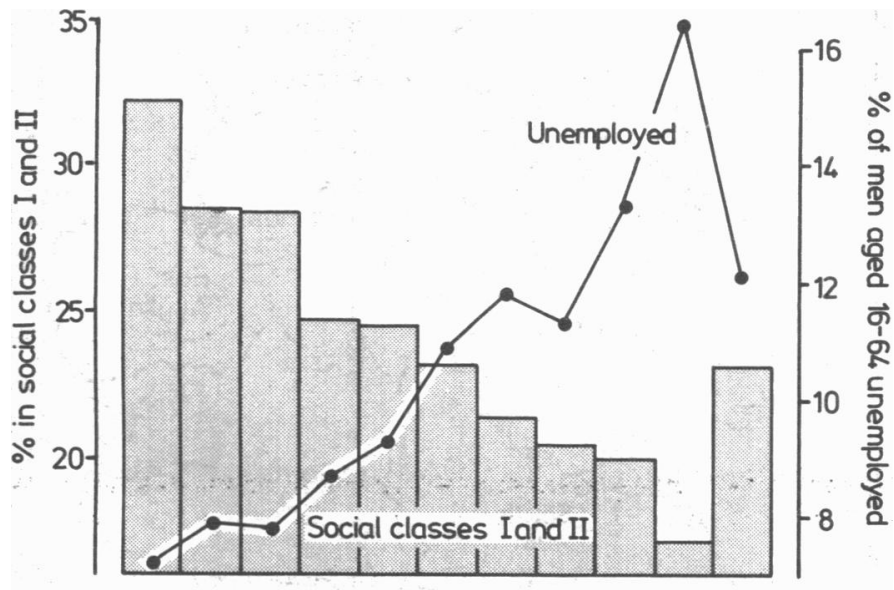

rural<2 2- 5- 10- 20- 50-100- 200-500-1000+ Population of urban area in thousands

FIG 2-Relation between social class composition and unemployment.

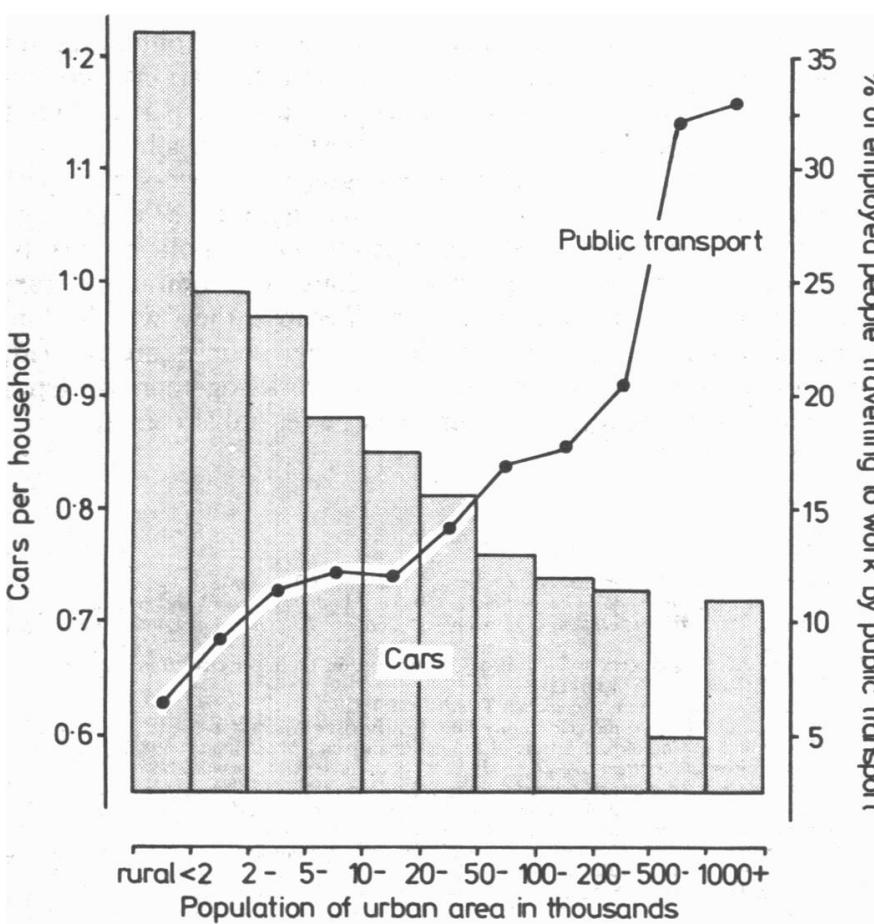

FIG 3-Access to private cars and use of public transport. counties. Without this the inner boroughs have to increase their rates and they are now penalised by central government for doing so.

\section{HEALTH IMPLICATIONS}

For most local authorities education takes the largest slice of funds, followed by housing and social services. The inner London boroughs are different. Education is run by a separate body (Inner London Education Authority) and thus social services are their biggest departments. This greater importance is reflected in substantially higher spending on personal social services in inner London boroughs than elsewhere in the country.

The dependence of the health services on adequate social services provision is well known. Policies for community care rely on a range of daycare and domiciliary services that are the statutory responsibility of local authorities. The previous Labour government started to transfer NHS resources to community care by joint financing, but, although this has been a useful initiative, joint financing only accounted for one 20th of social services spending in $1983-4 .^{\circ}$

The different boundaries and accounting systems of local government and the NHS make direct comparisons of finance from routine statistics impossible. In 1981 and 1982 the Social Services Committee of the House of Commons was able to create special tables comparing the two services. ${ }^{7}$ The table shows the lowest and highest in three categories of local authorities and their related area health authorities. The high cost teaching area health

Annual expenditure by local authorities on personal social services and related area health authorities, 1981-2

\begin{tabular}{|c|c|c|c|}
\hline - & Population & $\begin{array}{c}\text { Local } \\
\text { authority } \\
(£ \text { per head })\end{array}$ & $\begin{array}{c}\text { Health } \\
\text { authority } \\
(£ \text { per head })\end{array}$ \\
\hline \multicolumn{4}{|l|}{ Metropolitan districts } \\
\hline $\begin{array}{l}\text { Highest } \\
\text { Manchester } \\
\text { Newcastle upon Tyne }\end{array}$ & $\begin{array}{l}474100 \\
289800\end{array}$ & $\begin{array}{l}83 \\
70\end{array}$ & $\begin{array}{l}342 \\
338\end{array}$ \\
\hline $\begin{array}{l}\text { Lowest } \\
\text { Solihull } \\
\text { North Tyneside }\end{array}$ & $\begin{array}{l}198100 \\
192100\end{array}$ & $\begin{array}{l}24 \\
45\end{array}$ & $\begin{array}{l}136 \\
125\end{array}$ \\
\hline $\begin{array}{l}\text { London boroughs } \\
\text { Highest } \\
\text { Camden and Islington } \\
\text { Kensington, Chelsea, and Westminster }\end{array}$ & $\begin{array}{l}356100 \\
359000\end{array}$ & $\begin{array}{r}125 \\
94\end{array}$ & $\begin{array}{l}402 \\
435\end{array}$ \\
\hline $\begin{array}{l}\text { Lowest } \\
\text { Bromley } \\
\text { Enfield and Haringey }\end{array}$ & $\begin{array}{l}290300 \\
481100\end{array}$ & $\begin{array}{l}35 \\
61\end{array}$ & $\begin{array}{l}188 \\
163\end{array}$ \\
\hline $\begin{array}{l}\text { Non-metropolitan counties } \\
\text { Highest } \\
\text { East Sussex } \\
\text { Wiltshire }\end{array}$ & $\begin{array}{l}656200 \\
522800\end{array}$ & $\begin{array}{l}43 \\
28\end{array}$ & $\begin{array}{l}181 \\
209\end{array}$ \\
\hline $\begin{array}{l}\text { Lowest } \\
\text { Oxfordshire } \\
\text { Bedfordshire }\end{array}$ & $\begin{array}{l}371300 \\
503100\end{array}$ & $\begin{array}{l}25 \\
35\end{array}$ & $\begin{array}{l}162 \\
141\end{array}$ \\
\hline
\end{tabular}

authorities correlate with the higher spending local authorities. This might be expected, in that the teaching hospitals are mainly in old established industrial towns and in inner London. But the range of expenditure also matches. This is less expected, since local authorities provide services only for their own residents, whereas teaching health authorities have extra resources for referral and regional specialist services.

The data need more examination, and the Social Services Committee, in its 1982 report, recommended that "the Policy Strategy Unit might very usefully undertake an examination . . . to enable the Department to be in a position to assess the impact of spending changes in health and the personal social services." Nothing so far has been reported.

But, whereas the Resource Allocation Working Party has sought to level resources both upwards and downwards towards a mean which takes account of differences in need, ${ }^{8}$ rate capping and penalising high spending councils seem designed only to make services worse: there is no indication of policies for "levelling up" social services in underprovided authorities. 


\section{Discussion}

It is ironic that the government can write, in Streamlining the Cities, that "The reorganisations of the 1960s and early 1970s were typical of their time . . . the heyday of a certain fashion for strategic planning, the confidence in which now appears exaggerated."' In marked contrast, this same government is asking regional health authorities to improve their strategic planning and to control districts through subregional Resource Allocation Working Party target budgets.

Coordinated planning between healtn and local authorities is most needed for long term care of people with chronic handicaps, both mental and physical. In the first round of strategic planning of the late 1970s regions tended to concentrate their attention on developing a better pattern of acute hospital services. The current second round of plans propose major shifts from hospital to community care. Several regions have decided to close one or more hospitals for mental illness or mental handicap, and all regions are seeking ways to limit hospital stays of elderly physically and mentally infirm patients.

These humane strategies are foundering where social services departments are inadequately financed. Just when health service workers have woken up to the need to develop alternatives to institutional care, local authority spending to provide these services is being cut.

One answer is proposed by the government in the 1983 circular Care in the Community. ${ }^{9}$ This empowers health authorities to hand over their budgets for community care directly to local authorities. But such a proposal is unrealistic. People working in the health service are critical of the low levels of social services spending by many boroughs and counties, apparently designed to protect better off rate payers by ignoring the needs of their disadvantaged population. If these local authorities do not increase their own provision it is unlikely that health authorities will wish to subsidise them. On the other hand, there is little doubt that joint control of the community services budget would be an important step towards improving care. ${ }^{10}$

So perhaps it is time for a new approach to community care with both health and local authorities giving up some of their autonomy. Although changing the structure of health and social services once again will be greeted with little enthusiasm, there would be advantages. Care for mental illness, mental handicap, and the elderly could be provided as three joint user services, with the resources of health and social services pooled. Local authorities could be required to raise an agreed minimum level of spending (through rates and support grant combined), and be free to contribute more as local interest and resources permit. The NHS could contribute the agreed minimum levels of resources by care group, again with the option of transferring more from acute care if desired. These services would be jointly run by, and responsible to, a body similar to the present joint consultative committees.

While this would improve services at a local level (although counties, with several districts, will continue to have special problems), the opportunity could also be taken to match regional responsibilities. Germany, Italy, and France have moved, or are now moving, towards greater regional autonomy. In contrast, England does not have identical boundaries for its various regional services, and seems to be moving away from regionalism. Standard regions do exist for statistical purposes (fig 4). It could well be sensible to coordinate strategic planning between health and other local authority services at this level. The major difficulty for the NHS would be the size of the south east region. But as the local anomalies of the inner London hospitals get sorted out, through better local planning and the pressures of the Resource Allocation Working Party, a regional view including all London and the home counties becomes more sensible. And the role that the Greater London Council has started to develop in the past few years could come to fruition.

Let it be clear, however, that structural changes are not proposed as a way of saving money. Community services need more staff if they are to provide better long term care for people in their own homes. Our present levels of unemployment are the result of technical changes in our industries, poor national economic management, and failure of some industries to meet external competition. Whereas production of consumer goods can be mechanised with robots and electronic control, community care will necessarily remain labour intensive-and rightly so. The national profits of lower production costs must be passed, at least in part, to greater staff levels for social care.

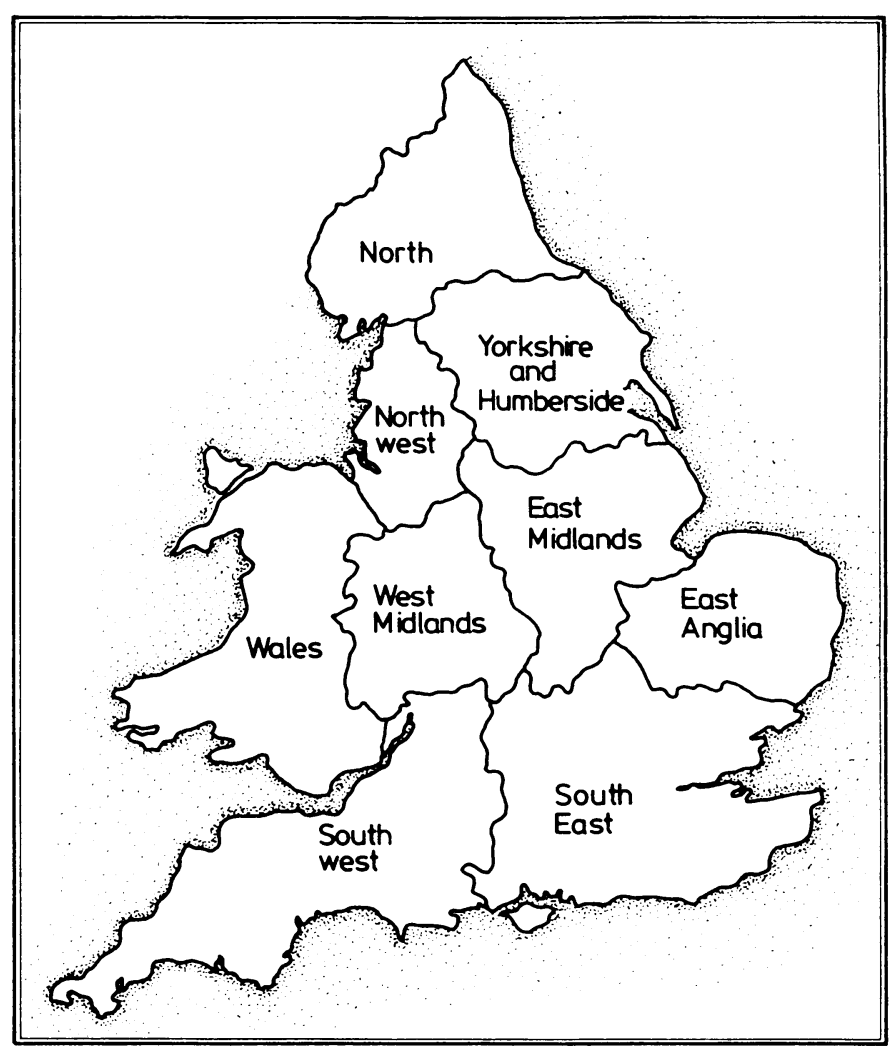

FIG 4-England and Wales: standard regions.

Short term monetarist theory suggests that public sector employment stifles economic growth. But greater national productivity yields a surplus that can be redistributed in part as better community care. The health and social services have a hard task in getting the present government to recognise the necessity to plan for higher levels of care, rather than trying to improve "efficiency" within capped budgets. The government's current policies must be rejected, both because they seek to constrain community care when it needs to be expanded, and because they will lead to reduced regional and local autonomy. New policies are needed, and health and local authorities should work together to plan a better future beyond the present years of centralist control.

\section{References}

I Department of the Environment. Streamlining the cities. London: HMSO, 1983. (Cmnd 9063 .) Anonymous. The future of the Greater London Council. London: Greater London Council, 1984. 1984

4 McCarthy M. New directions for primary health care in the inner city. Hospital and Health Services Review 1983;79(1):11-3.

Denham C. Urban Britain. Population Trends 1984;36:10-8.

Wistow G. Joint finance and community care. In: Harrison A, Gretton J, eds. Health care UK 1984. London: Chartered Institute of Public Finance and Accountancy, 1984

Social Services Committee. Second report from the social services committee 1981-2: 1982 white paper: public expenditure on the social services. London. HMSO, 1982

Desoure allocith

Department of Health and Social Security. Health service development: care in the community and 10 Glennester H. Client group budgeting: a prerequisite for efficient care. Public Money 1983;3(3):
25-8.

(Accepted 14 August 1984) 